\title{
INJURIES AND CONTUSIONS IN RECREATIONAL AND SPORTS HORSE RIDING
}

\author{
Rena Majchrowicz, ${ }^{A, B}$ Karolina Karaś,, , D Piotr Matłosz, ${ }^{D}$ Jarosław Herbert ${ }^{A, D}$ \\ Institute of Physical Culture Sciences, Medical College of Rzeszów University, Rzeszów, Poland

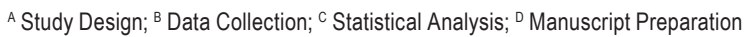 \\ Address for correspondence: \\ Jarosław Herbert \\ Towarnickiego 3c, 35-959 Rzeszów, Poland \\ E-mail: jherbert@ur.edu.pl
}

\begin{abstract}
Ahstract Horse riding is a satisfying and exciting sport and recreation activity. However, it is not without risk. A large percentage of riders experience accidents of varying degrees of severity during their professional and recreational careers. Any injury, even one that appears to be harmless, may turn out to be serious and exclude a competitor from sport for a long period of time. The purpose of the following research was to analyse the presence and incidence of contusions and injuries among novice and professional riders. The material for this study was collected using a research questionnaire conducted on a group of 1,973 people. Participants were chosen at random and belonged to an equestrian community from different age groups. The research was carried out all over Poland. Equestrianism is definitely an injurious physical activity, which is confirmed by the answer of $75 \%$ of respondents who consider this sport to have been harmful and have suffered an injury related to horse riding. Most respondents suffered hand contusions (45.5\%), concussion (25.4\%) and hand fractures (16.4\%). The strength of the study was the number of respondents $(1,973)$ and feedback on, among others, various types of injuries. These injuries can be easily avoided due to increased knowledge, practice, and education.
\end{abstract}

Key worlls horse riding, injury, contusion

\section{Introduction}

People have ridden horses since ancient times. In the beginning, the horse played a primarily utilitarian role, helping the rider travel over long distances or transport goods (Urban, 2018).

Horse riding is a form of sport, recreation, tourism and therapy with exceptional attributes and specificity (Sieńko-Awierianów, Łubkowska, Sitna, 2013; Wyżnikiewicz-Nawracała, 2002, p. 7). Riding is divided into seven disciplines: dressage, show jumping, eventing, combined driving, western riding, equestrian vaulting and endurance riding. The first three are included in the Olympic disciplines. There is also horse racing and polo (a team game played on a pitch consisting in getting the ball into the opponent's goal), which is more and more popular in Poland (Garnuszek, 2019).

Horse riding is one of the most popular recreational activities in Europe (Weber, 2017). In Sweden, almost 200,000 people are associated with this sport, which means that it takes eighth place in the ranking of "Most 
Popular Sport in the Country" (Altgarde, Redeen, Hilding, Drott, 2014). In New South Wales, 43,000 people under the age of 55 were involved in horse riding during a year (Roe et al., 2003; Angoules, Christakou, Tsibidakis, Angoules, Kapetanakis, 2019).

Many reports have shown the benefits of horse riding in terms of overall health, circulatory function (Kim, Lee, 2015) normal balance development and body movement (Whalen, Case-Smith, 2015). What's more, horse riding also has a positive effect on mental health, i.e., it relieves anxiety (Alfonso, Alfonso, Llabre, Fernandez, 2015), reduces hyperactivity (Hyun et al., 2016) or increases self-esteem (Hauge, Kvalem, Berget, Enders-Slegers, Braastad, 2014; Ohtani et al., 2017).

And what is very important, it is a form of physical activity that can be practiced from childhood to old age (Urban, 2013).

Horses are just animals whose behaviour and reactions we cannot be sure. Thus, if one wants to ride a horse,they have to take into account that injuries, cuts and accidents are part of the risk of this sport (Lisik, Napierała, Pezala, Zukow, 2014).

Despite the great interest in this form of activity, horse riding is considered one of the more injurious sports, and yet this sport is becoming increasingly popular in Europe. Injuries in horse riding can be divided into two types: systematic and random. Random injuries are caused by all kinds of falls. Systematic injuries arise as a result of prolonged action on the rider's body of powerful forces from the horse's back and the unnatural position of the rider's body during training. However, it is possible to help the rider by adjusting the saddle and riding equipment (Szypielewicz, Andryszczyk, Siemianowski, Topoliński, 2017). Injuries caused by horses have the highest likelihood of hospitalization based on patients using the US emergency services with injuries sustained by one of 250 monitored recreational activities. The hospital admission rate is $16.6 \%$ higher than for the next activity - off-road vehicles and motorcycle riding at $12.0 \%$ (United States Consumer Product Safety Commission, 2014). According to the sports injury register, a sports injury is one that prevents a player from participating in training or a tournament for at least one day after the event that caused it. A sports injury must take place during training or sporting events. Injuries may be the result of an excessive range of organ movement or maladjusted loading, and often occur during sports competitions where the competitor is forced to make more effort (Kraszewski, Kraszewska, 2013). Any injury, even one that appears to be harmless, may turn out to be serious and exclude a competitor from sport for a long period of time. The most serious injuries are head and spine injuries (Dobrzański, 1989).

A horse's strength can expose riders to potential injuries (Havlik, 2010). In the case of horse riding, it is estimated that one in five people who ride professionally and one in four who ride recreationally report back pain. It was also noticed that these ailments correlate with limited mobility of the spine (Dabek, Koczy, Piotrkowicz, 2015). The duration of the load is inversely proportional to the resistance of the spine. Constant loading on the spine causes its resistance to injury to decrease and its hardness to increase. The same happens with vibrations where at the moment when loads occur suddenly and the spine is exposed to rapid vibrations, the resistance to injuries will be much lower. The spine has too little time for natural adaptation to sudden vibrations (Dziak, Tayara, 1999).

To sum up, horse riders are exposed to an increased risk of injury (Eckert, Lockemann, Puschel, Meenen, Hessler, 2011; Smartt, Chalmers, 2009, Loder, 2008).

On the other hand, the overall incidence of injuries compared to other sports is described as rather low (Altgarde, Redeen, Hilding, Drott, 2014; Craven, 2008; Ghosh, Di Scala, Drew, Lessin, Feins, 2000). 


\section{Foundation and purpose of the research}

The purpose of the following research was to analyse the presence and incidence of contusions and injuries in novice and professional riders. The basic research questions relate to riding injuries and contusions and read as follows:

Is horse riding an injurious sport? Who suffers injuries and contusions most often? What factors contribute to injuries and contusions in this sport? Does the frequency of horse riding training matter?

The authors hypothesized that: Less frequent riders are more likely to get injured.

In order to obtain answers to the basic research questions and hypothesis, a diagnostic survey method based on the classic survey technique was used. As a research tool, allowing the collection of relevant data, a proprietary research questionnaire developed for the purposes of this study was sent to people who expressed a willingness to participate in the study and complete it.

The questionnaire consists of 11 questions. The questions, due to their diverse nature and detailed scope, allow us to build up a full picture of the causes of injuries in horse riding. In addition, the survey determines the profile of the respondent, obtaining information on their gender, age, education, and socio-professional status, which allows us to present a more complete profile of the respondents.

The results obtained during the study were analysed and presented using graphs, summarizing the collected materials and confirming or refuting the hypothesis, as well as answering the research questions.

The material for this study was collected using a research questionnaire conducted on a group of 1,973 people. Participants were chosen at random and belonged to an equestrian community from different age groups. The condition for participation in the research was horse riding, regardless of the discipline. The vast majority of the participants were women $-96.8 \%$. Men accounted for only $3.2 \%$ of all the respondents. The research was carried out all over Poland among people who agreed to take part in the study. Survey sheets were placed in thematic groups and equestrian-related social networks. The period in which the study was conducted was 3 months $(29.10 .2018-$ 29.01.2019). Information on completing the survey was included in the survey sheet. All people participating in the study were informed about the purpose of the study and the total anonymity of the answers given.

\section{Results}

The conduction of research, in which the main research tool was a questionnaire, resulted in obtaining results that allowed the examination of the hypothesis and research questions.

The sheet was completed by 1,973 study participants. The largest age group, i.e., 660 respondents (33.5\%) were people aged 16-18. A very similar number are the people up to 15 years old, who constituted 640 of the respondents (32.5\%). The next group are people aged $19-24$, who constitute 431 respondents $(21.8 \%)$. There were 88 people over 35 years old, which constituted $4.5 \%$ of the respondents.

The gender structure of the people who decided to answer the questions in the survey is arranged in a way that shows a clear advantage of the group of women, which constituted $96.8 \%$, i.e., 1909 of the total number of respondents. 64 men participated in the survey, which constitutes $3.2 \%$ of respondents.

Of all the respondents, the largest group were people declaring school pupil status $-1,334(67.6 \%)$. The second group was made up of employed persons - 339 (17.2\%). The next group were students - 280 (14.2\%). The least numerous group were unemployed people, who numbered 15 , which is $0.8 \%$ of respondents. 
The first question in the questionnaire about horse riding injuries and contusions concerned how long the respondent has been riding. Most respondents, as many as 928 , have been riding for 7 years or more, which is $47 \%$ of the total. The next group is people who have been riding for 4 to 6 years, they constitute $32.9 \%$, i.e., 649 respondents, and persons riding from 1 to 3 years constitute 17.3\%, i.e., 342 respondents. The smallest group is the group of respondents who have been riding for less than a year $-54(2.7 \%)$.

The second question concerned the frequency of horse riding training. Most respondents - $589(29.9 \%)$ ride only once a week, 2 times a week - 491 respondents (24.9\%), 3-4 times a week - 454 respondents (23\%), 5-6 times a week - 328 people (16.6\%), and the smallest group of respondents ride 7 times a week - $111(5.6 \%)$.

The third question concerns the amount of time that the respondent devotes to riding per day. Most of the respondents spend 1 to 2 hours a day (1,207 people, 61.2\%). Another large group are people who devote up to 1 hour a day - 418 people (21.2\%). 211 people (10.7\%) spend between 2 and 3 hours on horseback, 77 people (3.9\%) 3 to 4 hours, and 60 people (3\%) 4 or more hours.

In the fourth question, the respondents who additionally indicated other physical activity were asked about the type of activity they practiced. Many of the people also ride a bicycle: $579(39.3 \%)$, the next popular activity is running: 518 respondents (35.2\%), volleyball: 479 people (32.5\%), roller skating: 370 people (25.1\%), swimming: 348 (23.6\%), gymnastics: $301(20.4 \%)$, basketball: 185 (12.6\%), handball: $121(8.2 \%)$, football: $95(6.5 \%)$, gym training: $57(3.9 \%)$, dance: $28(1.9 \%)$, aerobics $11(0.7 \%)$, yoga $11(0.7 \%)$, others $165(11.2 \%)$.

The fifth question concerned what form of horse riding the respondent did. A total of 1,973 people responded, of which 824 respondents (41.8\%) ride recreationally around a square, $715(36.2 \%)$ ride for sport, $672(34.1 \%)$ ride recreationally in the fields, 641 (32.5\%) ride for sport and compete in equestrian competitions, other answers: $60(3.0 \%)$.

The sixth question was about equestrian injuries. 1,415 people $(71.7 \%)$ responded that they had suffered an equestrian injury, 558 people (28.3\%) had never suffered an injury.

The seventh question was optional and concerned the type of contusion or injury suffered. 1,388 people answered them. Most respondents suffered: hand contusions: 632 (45.5\%), concussion: $352(25.4 \%)$, hand fractures: 227 (16.4\%), ligament ruptures: 189 (13.6\%), dislocations and contusion of the shoulder joint: $172(12.4 \%)$, knee damage: 107 (7.7\%), ankle injuries: 82 (5.9\%), spinal injuries other than fractures and bruises: $65(4.7 \%)$, finger dislocations or fractures: 60 (4.3\%), spine fractures: $52(3.7 \%)$, rib injuries: 51 (3.7\%). Other injuries are leg injuries other than fractures: $47(3.4 \%)$, leg fractures: $39(2.8 \%)$, metatarsal bone injuries: $33(2.4 \%)$, spinal contusions: $30(2.2) \%)$, vertebral and cervical muscle injuries: $27(1.9 \%)$, collarbone fracture: $24(1.7 \%)$ and other than those mentioned: 265 (19.1\%).

The eighth question required respondents to answer a question about a recovery break in training caused by an injury. The answer to this question was obligatory only for those who have suffered an injury. A total of 1,661 responses were obtained, of which $1,140(68.6 \%)$ replied that a break was required after the injury. $521(31.4 \%)$ of the subjects could return to sports training immediately after the injury.

The next question was about the feeling and recurrence of the effects of injury. The question was optional and was answered in total by 1,568 people. 858 respondents (54.7\%) answered that the effects of the injury returned. 710 people $(45.3 \%)$ did not feel any effects of their injuries.

The penultimate question concerned the symptoms felt after the injury. 1,130 people answered them. Most respondents indicated that they felt pain - 957 people (84.7\%). In addition, many riders felt a tearing sensation - 
301 people (26.6\%) and twinging: 260 people (23\%). Only 62 respondents $(5.5 \%)$ indicated feeling different symptoms than those listed in the questionnaire.

The final question concerns the self-assessment of the respondent's physical fitness. The question was obligatory. 974 people (49.4\%) assess their physical fitness at a good level. 611 respondents (31\%) at a very good level. 357 people assess their physical fitness at an average level (18.1\%), and $26(1.3 \%)$ at a poor level. None of the survey participants rated their fitness at a very poor level.

In addition, the work compares data on the occurrence of injuries depending on the age of the respondents. In the group of the youngest and oldest riders, injuries occurred less frequently than in other groups (20 $\pm 5 \%$ difference) (Figure 1).

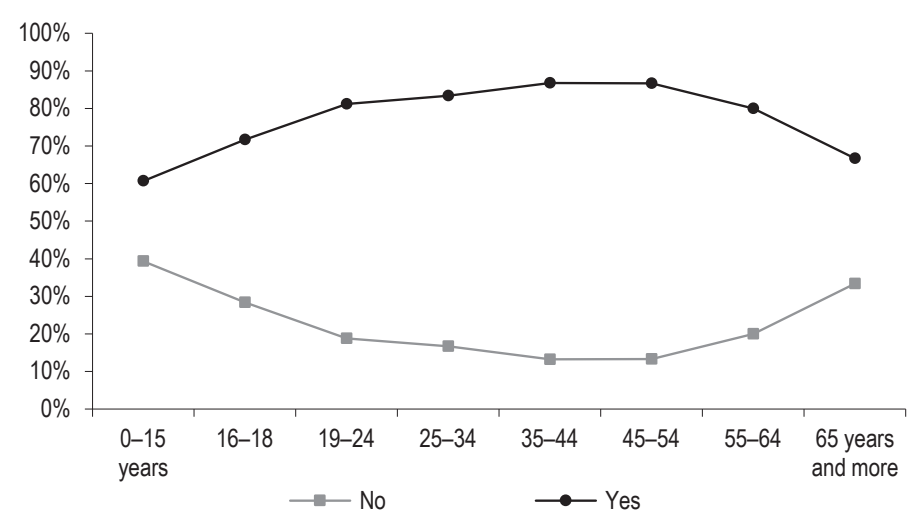

Figure 1. Occurrence of injuries depending on the age of the respondents

Source: based on own research.

The work also summarizes the occurrence of injury depending on training experience (Figure 2).

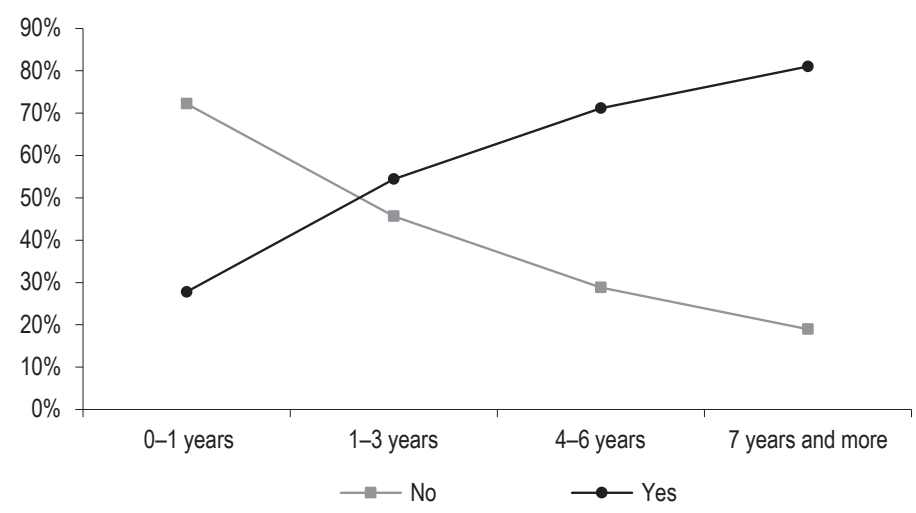

Figure 2. Occurrence of injury depending on training experience

Source: based on own research. 


\section{Discussion}

Horse riding is widespread worldwide as a sport and recreational physical activity. It is associated with a significant risk of accidents and injuries of the musculoskeletal system (Lang et al., 2014; Boran, Lenehan, Street, McCormack, Poynton, 2011).

Frequent troubles and problems arise from the fact that the horse may not understand what is expected from it. Therefore, the horse may be upset and stressed, which may result in, for example, throwing the rider off (Mickunas, 2006, 263).

It is also important not to overestimate your own abilities, to be able to anticipate certain situations and possible behaviour of the horse (Grobelny, Jasiński, 1997).

Initial observations and analysis of the literature devoted to horse riding leads to the conclusion that horse riding is an injurious sport, both at the beginner level and at the level of advanced people who ride more often and with greater risk.

The research on a group of people associated with horse riding carried out using a questionnaire survey allowed us to achieve the assumed goal in this work. On its basis, we can answer the research questions posed earlier.

Equestrianism is definitely an injurious physical activity, which is confirmed by the answer of $75 \%$ of respondents who consider this sport to have been harmful and have suffered an injury related to horse riding. Based on experience one can agree with the respondents. It is not an easy sport, and yet, people who have not tried riding consider it a low-risk sport. These results confirm the research (Carmichael, Davenport, Kearney, Bernard, 2014; Hasler et al. 2011; Wolińska, Łuczyńska, Jaworski, 2012).

Most injuries happen by falling from the horse, which is more likely among people who are not accustomed to the specific behaviour and movement of the horse, and often panic, acting in an irrational way. Most often they are people riding recreationally, once a week, for about an hour.

Age is not significant in the occurrence of injuries; they happen both in the elderly and younger people. Although older people would appear more prone to injury, unlike young people, they have a more developed ability to predict.

In the research of Srinivasan, Pierre, Plog, Srinivasan, Petraglia, Huang (2014) the percentage of women who suffered neurological injury associated with equestrian sport is higher and equal to $54 \%$, with younger women being more at risk.

One of the many ways to avoid injuries is to increase the frequency of riding, which will allow a person to better master horse riding and get used to the specific movement and behaviour of the horse. Injuries in this sport are very diverse, from head to toe. Very often they require a longer break after suffering an injury due to long-term effects. Several studies have shown that more experienced riders are safer and suffer fewer injuries (Loder, 2008; Mayberry, Pearson, Wiger, Diggs, Mullins, 2007; Guyton, Houchen-Wise, Peck, Mayberry, 2013).

At the start of the study, the following hypothesis was made: Less frequent riders experience injuries more often. As a result of applying the survey questionnaire tool and analysing the obtained test results, the hypothesis was not confirmed. People who ride less often experience decidedly fewer injuries. Injuries are caused by simple mistakes, such as a rider leaving their leg in a stirrup when they fall, girth failure when getting on or while riding, incorrect fitting of equipment, inadequate response to horse behaviour, screaming or sudden movements when the rider begins to feel fear. The research results show that as the training period increases, the likelihood of injuries increases (Figure 2). 
Often the primary reason for falling from a horse is that the horse was afraid or was surprised and reacted in a way that caused injury to the rider (Srinivasan, Pierre, Plog, Srinivasan, Petraglia, Huang, 2014). Riders must always remain aware of the animal's unpredictable nature.

In summary, this study outlined the presence and incidence of contusions and injuries for beginner and professional riders. Equestrianism can lead to many injuries from very small to serious and even fatal. Research results emphasize that horse riding as well as horse handling carries the risk of serious injuries, and the most common injuries are hand contusions: 632 (45.5\%) and concussions: 352 (25.4\%).

A strength of the study was the number of respondents (1973) and feedback on, among others, various types of injuries. These injuries can be easily avoided due to increased knowledge, practice, and education. The authors believe that if the number of injuries can be reduced more people will be able to enjoy riding.

It is imperative that riders learn equine behaviour and safety practices around horses to prevent the majority of accidents while on the ground. A significant reduction in the injuries and contusions of equestrians could be obtained with the use of safety equipment (helmets, vests).

\section{References}

Alfonso, S.V, Alfonso, L.A, Llabre, M.M, Fernandez, M.I. (2015). Roject stride: an equine-assisted intervention to reduce symptoms of social anxiety in young women. Explore (NY), 11, 461-467. DOI: 10.1016/j.explore.2015.08.003.

Altgarde, J., Redeen, S., Hilding, N., Drott, P. (2014). Horse-related trauma in children and adults during a two year period. Scand J Trauma Resusc Emerg Med, 22, 40.

Angoules, A., Christakou, A., Tsibidakis, H., Angoules, G.A., Kapetanakis, S. (2019). Horse-related spine and spinal cord injuries in horse riding: The New South Wales experience 1976-1996. ANZ J Surg. DOI: 10.15761/CSRR.1000122

Boran, S., Lenehan, B., Street, J., McCormack, D., Poynton, A. (2011). A 10-year review of sports-related spinal injuries. Ir J Med Sci, 180, 859-863.

Carmichael, S.P., Davenport, D.L., Kearney, P.A., Bernard, A.C. (2014). On and off the horse: Mechanisms and patterns of injury in mounted and unmounted equestrians. Injury, 45, 1479-1483.

Craven, J.A. (2008). Paediatric and adolescent horse-related injuries: does the mechanism of injury justify a trauma response? Emerg Med Australas, 20, 357-362.

Dąbek, J., Koczy, B., Piotrkowicz, J. (2015). Horse riding as a form of recreation and professional sport taking into account the spine mobility of riders - a preliminary results. Polski Merkuriusz Lekarski, 39, 297-304.

Dobrzański, T. (1989). Medycyna wychowania fizycznego i sportu. Warszawa: Sport i Turystyka.

Dziak, A., Tayara, S. (1999). Urazy i uszkodzenia w sporcie. Kraków: Kasper.

Eckert, V., Lockemann, U., Puschel, K., Meenen, N.M., Hessler, C. (2011). Equestrian injuries caused by horse kicks: first results of a prospective multicenter study. Clin J Sport Med, 21, 353-355.

Garnuszek, J. (2019). Wprowadzenie Skoki. Retrieved from: http://www.pzj.pl/sport/wprowadzenie.

Ghosh, A., Di Scala, C., Drew, C., Lessin, M., Feins, N. (2000). Horse-related injuries in pediatric patients. J Pediatr Surg, 35, 1766-1770.

Grobelny, J., Jasiński, J. (1997). Formy rekreacji konnej w zależności od wieku i poziomu umiejętności jeździeckich. In: D. Umiastowska (red.), Aktywność ruchowa ludzi w różnym wieku (pp. 15-18). Szczecin: Uniwersytet Szczeciński.

Guyton, K., Houchen-Wise, E., Peck, E., Mayberry, J. (2013). Equestrian injury is costly, disabling, and frequently preventable: the imperative for improved safety awareness. Am Surg, 79, 76-83.

Hasler, R.M., Gyssler, L., Benneker, L., Martinolli, L., Schötzau, A., Zimmermann, H., Exadaktylos, A.K. (2011). Protective and risk factors in amateur equestrians and description of injury patterns: A retrospective data analysis and a case - Control survey. J Trauma Manag Outcomes, 5, 4.

Hauge, H., Kvalem, I.L., Berget, B., Enders-Slegers, M.J., Braastad, B.O. (2014). Equine assisted activities and the impact on perceived social support, self-esteem and self-efficacy among adolescents - an intervention study. Int J Adolesc Youth, 19, 1-21. DOI: 10.1080/02673843.2013.779587. 
Havlik, H.S. (2010). Equestrian sport-related injuries: a review of current literature. Curr Sports Med Rep, 9, 299-302.

Hyun, G.J., Jung, T.W., Park, J.H., Kang, K.D., Kim, S.M., Son, Y.D., Cheong, J.H., Kim, B.N., Han, D.H. (2016). Changes in gait balance and brain connectivity in response to equine-assisted activity and training in children with attention deficit hyperactivity disorder. J Altern Complement Med, 22 (4), 286-293. DOI: 10.1089/acm.2015.0299.

Kim, Y., Lee, D. (2015). Effects of horse-riding exercise on balance, gait, and activities of daily living in stroke patients. J Phys Ther Sci., 27, 607-609. DOI: 10.1589/jpts.27.607.

Kraszewski, K., Kraszewska, A. (2013). Drogi życiowe sportowców po urazach uniemożliwiających dalszą karierę- aspekty psychologiczne, „Фізичне виховання, спорт і здоров я людини” (рp. 284-288). Kamieniec Podolski: Narodowy Uniwersytet im. Iwana Ogienki w Kamieńcu Podolskim.

Lang, J., Sathivelu, M., Tetsworth, K., Pollard, C., Harvey, K., Bellamy, N. (2014). The epidemiology of horse-related injuries for different horse exposures, activities, and age groups in Queensland, Australia. J Trauma Acute Care Surg, 76, 205-212.

Lisik, M., Napierała, M., Pezala, M., Zukow, W. (2014). Urazy i kontuzje w jeździectwie w opinii osób uprawiających sporty konne. Journal of Health Sciences, 4 (15), 29-41.

Loder, R.T. (2008). The demographics of equestrian-related injuries in the United States: injury patterns, orthopedic specific injuries, and avenues for injury prevention. J Trauma, 65, 447-460.

Mayberry, J.C., Pearson, T.E., Wiger, K.J., Diggs, B.S., Mullins, R.J. (2007). Equestrian injury prevention efforts need more attention to novice riders. J Trauma, 62, 735-973.

Mickunas, W. (2006). Trener radzi. Jak lepiej poznać konie, lepiej je zrozumieć i lepiej na nich jeździć. Łódź: Galaktyka.

Ohtani, N., Kitagawa, K., Mikami, K., Kitawaki, K., Akiyama, J., Fuchikami, M., Uchiyama, H., Ohta, M. (2017). Horseback Riding Improves the Ability to Cause the Appropriate Action (Go Reaction) and the Appropriate Self-control (No-Go Reaction) in Children. Front. Public Health, 5, 8.

Roe, J.P., Taylor, T.K., Edmunds, I.A., Cumming, R.G., Ruff, S.J., Plunkett-Cole, M.D., Mikk, M., Jones, R.F. (2003). Spinal and spinal cord injuries in horse riding: the New South Wales experience 1976-1996. ANZ J Surg.; 73 (5), 331-334.

Sieńko-Awierianów, E., Łubkowska, W., Sitna, A. (2013). Czynniki warunkujące uczestnictwo w rekreacji jeździeckiej. Ekonomiczne Problemy Turystyki, 4 (24), 85-101.

Smartt, P., Chalmers, D. (2009). A new look at horse-related sport and recreational injury in New Zealand. J Sci Med Sport, 12, $376-382$.

Srinivasan, V., Pierre, C., Plog, B., Srinivasan, K., Petraglia, A.L., Huang, J.H. (2014). Straight from the horse's mouth: neurological injury in equestrian sports. Neurol Res, 36, 873-877.

Szypielewicz, S., Andryszczyk, M., Siemianowski, P., Topoliński, T. (2017). Analiza biomechaniki kręgosłupa w jeździectwie. Aktualne Problemy Biomechaniki, 13, 57-62.

United States Consumer Product Safety Commission (2014). 2014 calendar year national electronic injury surveillance system. Retrieved from: www.cpsc.gov/en/research-statistics/NEISS-Injury-Data.

Urban R. (2013). Turystyka jeździecka w Polsce - tradycje i teraźniejszość. Zarys problematyki. In: R. Pawlusiński (ed.), Współczesne uwarunkowania i problem rozwoju turystyki. Kraków: IGiGP Uniwersytet Jagielloński.

Urban, R. (2018). Polish Contribution to the Development of Views on Horse Riding as a Form of Therapy - a Brief Historical Retrospection. Central European Journal of Sport Sciences and Medicine, 3 (23), 17-24. DOI: 10.18276/cej.2018.3-02.

Weber, C.D., Nguyen, A.R., Lefering, R., Hofman, M., Hildebrand, F., Pape, H-C.H. (2017). Blunt injuries related to equestrian sports: results from an international prospective trauma database analysis. Int Orthop, 41, 2105-2112.

Whalen, C.N., Case-Smith, J. (2012). Therapeutic effects of horseback riding therapy on gross motor function in children with cerebral palsy: a systematic review. Phys Occup Ther Pediatr, 32, 229-242. DOI: 10.3109/01942638.2011.619251.

Wolińska, K., Łuczyńska, M., Jaworski, Z. (2012). Analiza zaburzeń behawioralnych u koni rekreacyjnych w wybranych ośrodkach jeździeckich województwa pomorskiego i warmińsko-mazurskiego. Roczniki Naukowe Polskiego Towarzystwa Zootechnicznego, 8 (1)

Wyżnikiewicz-Nawracała, A. (2002). Jeździectwo w rozwoju motorycznym i psychospołecznym osób niepełnosprawnych. Gdańsk: Akademia Wychowania Fizycznego i Sportu, Gdańsk.

Cite this anticle aS: Majchrowicz, R., Karaś, K., Matłosz, P., Herbert, J. (2021). Injuries and Contusions in Recreational and Sports Horse Riding. Central European Journal of Sport Sciences and Medicine, 1 (33), 73-80. DOI: 10.18276/cej.2021.1-07. 